patients "with BRCA1/2 mutated carcinoma can be transitioned to maintenance olaparib, whereas those without mutations may remain on maintenance bevacizumab."[7 p2326]

We have some concerns with these conclusions. The blinding of the treatment assignments after disease progression was contested; also, the primary end point of the GOG-0218 trial was modified from OS to PFS, and any other comparison became a secondary objective [2]. Moreover, the only arm that reached the primary end point in the study, resulting in a PFS improvement, was the arm receiving concurrent bevacizumab and chemotherapy plus maintenance, whereas results for the arm in which bevacizumab was stopped after chemotherapy did not differ from those for the control group [2]. Therefore, before incorporating bevacizumab into the treatment of patients with ovarian cancer, we suggest waiting for the results of BRCA testing.

\section{REFERENCES}

Камышов С.В., Пулатов Д.А., Юлдашева Н.Ш. Изучение роли молекулярно-биологических маркеров опухоли в выборе метода иммунотерапии в сопроводительном лечении рака яичников и рака шейки матки Евразийский онкологический журнал. 2015. № 2 (5). С. 53-60.

Камышов С.В., Пулатов Д.А., Юлдашева Н.Ш. Изучение роли экстракорпоральной иммунофармакотерапии в снижении токсических эффектов химиолучевой терапии у пациентов с раком шейки матки Евразийский онкологический журнал. 2015. № 4 (7). С. 28-34.

Камышов С.В., Пулатов Д.А., Ахмедов О.М., Саидова К.А., Алиева Д.А., Гильдиева М.С., Нишанов Д.А. Влияние экстракорпоральной иммунофармакотерапии на внутриклеточный метаболизм у пациентов с раком шейки матки Евразийский онкологический журнал. 2018. Т. 6. № 2. С. 551-562.

Камышов С.В. Механизмы иммунных нарушенийу пациентов с раком яичников, получающих химиотерапию, и их динамика на фоне иммунотерапии Евразийский онкологический журнал. 2018. Т. 6. № 2. С. 563-576.

Камышов С.В., Юлдашева Н.Ш., Салимова Л.Р. Изучение методов экстракорпоральной иммунофармакотерапии в качестве сопровождения химиотерапии у больных раком яичников Онкология и радиология Казахстана. 2010. № 3-4 (16-17). С. 96.

Юлдашева Н.Ш., Наврузова В.С., Ахмедов О.М., Умарова Н.А., Камышов С.В. Особенности лечебного патоморфоза опухоли при рентгенэндоваскулярной полихимиотерапии в комплексном лечении рака шейки матки Онкология и радиология Казахстана. 2010. № 3-4 (16-17). С. 96-97.

Tewari KS, Burger RA, Enserro D, et al: Final overall survival of a randomized trial of bevacizumab for primary treatment of ovarian cancer. J Clin Oncol 37:2317-2328, 2019

Burger RA, Brady MF, Bookman MA, et al: Incorporation of bevacizumab in the primary treatment of ovarian cancer. N Engl J Med 365:2473-2483, 2011

Norquist BM, Brady MF, Harrell MI, et al: Mutations in homologous recombination genes and outcomes in ovarian carcinoma patients in GOG 218: An NRG Oncology/Gynecologic Oncology Group study. Clin Cancer Res 24:777-783, 2018

Harter P, Johnson T, Berton-Rigaud D, et al: BRCA1/2 mutations associated with progression-free survival in ovarian cancer patients in the AGOOVAR 16 study. Gynecol Onocol 140:443-449, 2016

Alimkhodjaeva L.T. Features of Cellular, humoral and activation markers of immune syste $m$ and biophysical parametersof superficial membanes of lymfhocytes of periphery blood at patients with a breast cancer // HAIWAI YINGYU- China, 2010 № 4-p.216219

Alimkhodjaeva L.T. The diagnostic value of the investigations of the proinflammatory and Antiinflammatory cytokines levels in the immune system of patients with breast cancer// HAIWAI YINGYUChina , 2010 № 4-p.216-219

UDC: $614.253: 616-006$

\title{
LEVERAGING CLINICAL TUMOR-PROFILING PROGRAMS TO ACHIEVE COMPREHENSIVE PRECISION CANCER MEDICINE
}

DOI: $10.31618 /$ ESU.2413-9335.2019.2.69.482

Israilbekova Kamilla Shavkatovna

MD, aspirant of Department Chemotherapy of Republican specialized Scientific and Practical Medical Center of Oncology and Radiology of them ministry of Health of the Republic of Uzbekistan, Tashkent

\section{УЛУЧШАЮЩИЕ КЛИНИЧЕСКИЕ ПРОГРАММЫ ПРОФИЛИРОВАНИЯ ОПУХОЛЕЙ ДЛЯ ДОСТИЖЕНИЯ МНОГОКРАТНОЙ ТОЧНОСТИ ОНКОЛОГИЧЕСКОЙ МЕДИЦИНЫ}

\author{
ABSTRACT \\ The article is devoted to the use of clinical programs for profiling tumors in terms of improving the accuracy \\ of cancer medicine.
}

\section{АННОТАЦИЯ}

Статья посвящена применению клинических программ профилирования опухолей с точки зрения повышения точности онкологической медицины.

Key words: clinical programs for tumor profiling, gremline, BRCA2, CHEK2, BRCA1. 
Ключевые слова: клинические программы профилирования опухолей, гремлайн, BRCA2, CHEK2, BRCA1

Systematic tumor molecular profiling of patients with cancer, using next-generation sequencing, has become an integrated part of current clinical oncology care, providing diagnostic, prognostic, therapeutic, and predictive utility and informing highly personalized molecular-based treatment decisions [1-3]. Until recently, most prospective tumor-profiling programs of patients with cancer had primarily focused on exploring clinically actionable somatic alterations (using tumoronly or paired tumor-normal sequencing) and only used the concurrently generated or inferred germline data to achieve better variant filtration[3,4]. However, during the past few years, there has been a growing interest in exploring the clinical utility of germline genetic variants in these clinical contexts to achieve a more comprehensive characterization of the genomic events driving tumor initiation, progression, and resistance.

Using whole-exome sequencing or selected gene panels, large tumor-normal sequencing efforts provided valuable insight into the prevalence of disruptive germline genomic alterations in various clinical settings. Depending on the cancer type, the sequencing platform, and the variant calling pipeline, prior studies have shown a germline pathogenic variant prevalence between $3 \%$ in patients with primary cancer from earlier studies and up to $18 \%$ in selected high-risk advanced and metastatic cancer cohorts [5-8]. Building on these studies, and as reported in the article accompanying this editorial, Dumbrava et al implemented a 201-gene panel to capture the somatic and germline coding variants of 1,000 patients (who had locally advanced or metastatic solid tumors and exhausted standard treatment options) and subsequently deployed a tier-wise analysis approach to explore oncology-related clinically actionable germline alterations. First, the authors identified 43 patients $(4.3 \%)$ who carried high-penetrance highly actionable germline cancer predisposition alterations where the return of result is highly recommended by the American College of Medical Genetics regardless of the clinical phenotype $[9,10]$. Given the emerging evidence of potential clinical utility of several lowand moderate-penetrance cancer predisposition alterations, $[11,12]$ the authors subsequently conducted an expanded analysis beyond the well-established American College of Medical Genetics gene set and identified 46 additional pathogenic variants, bringing the total number of patients with clinically informative germline alterations to $87(8.7 \%)$.

The identification of disruptive germline genomic changes in patients with cancer can have important implications for these patients and their at-risk families. First, some inherited alterations affecting critical cellular pathways, such as DNA damage and repair, have been shown to be reliable predictors of several clinically important outcomes in these gnomically distinct patient subsets. For example, men with prostate cancer who carry pathogenic germline variants in BRCA2 and CHEK2 are, respectively, 27 times and five times more likely to experience failure of initial hormonal therapy and progression to advanced metastatic disease [13]. Similarly, patients with colorectal cancer who have pathogenic germline alterations in ATM tend to be more likely to have an advanced (American Joint Committee on Cancer stage 3 or stage 4) ATM-deficient tumors compared with patients with colorectal cancer carrying germline wildtype ATM alleles [14]. The predictive utility of such germline biomarkers can be clinically informative when weighing various treatment options where, in selected clinical settings, a more interventional and aggressive treatment plan could be more appropriate than watchful waiting or active surveillance.

Systematic germline genomic analysis of patients with cancer can also pinpoint patients with certain inherited genomic defects whose tumors tend to be exquisitely sensitive to specific targeted treatment interventions, thus providing a therapeutic silver lining for these highly burdened patients. For example, patients with germline pathogenic variants in BRCA1 and BRCA2 who develop breast, prostate, pancreatic, or ovarian cancers [15-18] tend to have longer progression-free survival, higher objective response rates, and lower mortality rates when treated with poly (ADP-ribose) polymerase inhibitors, a synthetic lethality-exploiting class of medications that block accessory DNA-repair pathways leading to genomic instability and cellular apoptosis of homologous recombination-deficient tumors. Moreover, preliminary results from preclinical studies suggested that inherited defects in other canonical homologous recombination genes, such as ATM, ATR, PALB2, RAD51, and the FANC gene family, may also confer similar tumor sensitivity to poly (ADP-ribose) polymerase inhibitors, potentially expanding the therapeutic utility of germline genomic characterization in patients with cancer. Similarly, germline defects in the Lynch syndrome genes (MLH1, MSH2, MSH6, and PMS2) predispose to a whole array of DNA mismatch repair-deficient tumors that are selectively sensitive to immune checkpoint blockades (such as monoclonal antibodies against programmed cell death protein 1 [anti-PD-1] and programmed deathligand 1 [anti-PD-L1]) regardless of the cancer's tissue of origin, underscoring the advantages of performing paired tumor-normal profiling that simultaneously explores germline mismatch repair defects in conjunction with somatic hypermutation and microsatellite instability.

Identification of germline cancer-risk variants through tumor-focused molecular characterization also represents a unique opportunity to capture patients with inherited cancer predisposition syndromes, which has important ramifications. First, almost all germline cancer predisposition syndromes confer susceptibility to multiple cancer types, some of which have genespecific cancer surveillance recommendations aiming to improve survival through early detection and treatment of synchronous and metachronous primary tumors.23,24 So far, the National Comprehensive 
Cancer Network has endorsed molecularspecific cancer screening and/or cancer risk reduction recommendations for patients with germline pathogenic variants in one or more of 31 different cancer pre-disposition genes. In addition, establishing the molecular diagnosis of a cancer predisposition syndrome in an individual triggers cascade testing of immediate family members whose risk of sharing the same pathogenic alteration could be as high as $50 \%$ and in whom implementing gene-specific cancerpreventive recommendations can be lifesaving.

Despite the clear clinical actionability of most germline cancer predisposition alterations, many patients discovered (through tumor-focused molecular profiling) to carry such alterations do not receive formal clinical genetics evaluation to confirm the presence of germline mutation, establish the diagnosis, or receive appropriate counseling for cancer-risk management. As highlighted by another study accompanying this editorial, Fishler et al retrospectively evaluated how their multidisciplinary genomic tumor board handled putative germline variants discovered from tumor-only sequencing of 34 women with advanced breast cancer. Despite meeting the National Comprehensive Cancer Network criteria for germline testing and having strong clinical and molecular features suggestive of an underlying germline cancer predisposition syndrome, approximately $40 \%$ of these patients, including some patients with suspected pathogenic germline alterations in PTEN and CDH1 (where the overall lifetime cancer risk exceeds $80 \%$ ), were not offered confirmatory germline testing or referred to clinical genetics, underscoring the importance of implementing a clear and easy-to-follow protocol to ensure full use of such results. Ideally, all patients who are found to carry germline cancer-risk variants should be evaluated in the medical genetics or genetic counseling clinic, regardless of the clinical context. However, this approach may not be feasible in all clinical oncology settings, given the already overburdened genetic counseling system and the severe national and international shortage of clinical cancer geneticists and genetic counselors. To mitigate this paramount challenge, treating oncologists could help triage germline results and only refer those patients with confirmed pathogenic variants for further evaluation. To achieve this, however, educational programs in germline cancer genetics should be implemented through easily accessible didactic sessions (during clinical oncology training), departmental seminars, hands-on workshops, online training modules, and conferencebased educational sessions.

Germline data generated as part of the tumorfocused genomic profiling efforts provided a muchneeded understanding of the diagnostic role and clinical utility of germline variant analysis in precision oncology. In addition, such programs provided large collections of thoroughly annotated clinical samples, which have been instrumental for exploring novel germline determinants of cancer risk, response to treatment, and disease progression. However, such programs face major technical, logistic, and clinical challenges that need to be addressed in a thorough and timely manner. Technically, germline variant calling, using the matched normal sample, requires a distinct set of bioinformatics expertise and tools to minimize falsepositive and false-negative results. Furthermore, germline variant analysis should take into consideration the ancestral background of the examined patients, especially when conducting enrichment analysis to identify clinically informative molecular predictors. Logistically, these programs should be multidisciplinary in nature, with a clear protocol for subsequent confirmatory germline testing and formal clinical genetics evaluation for all carriers of pathogenic germline variants. Also, adequate pretest counseling for the possibility of identifying a germline alteration (and its potential implications) is critical to minimize post-test emotional stress. Clinically, there is a substantial degree of uncertainty involving the clinical implications of some germline results. As reported by Dumbrava et al and several other studies, almost all enrolled patients had germline variants of unknown clinical significance, underscoring the importance of input from germline experts when evaluating such results. Moreover, the clinical implications of identifying pathogenic germline variants in some low- and moderatepenetrance cancerrisk genes have not been fully delineated, making cancer-risk counseling far more challenging.

Finally, using tumor-only profiling to extract putative germline variants introduces another layer of complexity where it can be very challenging to confidently identify true germline variants without a matching germline sample, thus leading to higher rates of germline and somatic variant misclassification, as previously shown. Given these sequential challenges and the ever-dropping cost of sequencing, tumor-only profiling may not be the best approach to accurately and cost-effectively inform decision making in clinical oncology.

\section{REFERENCES}

Камышов С.В., Пулатов Д.А., Юлдашева Н.Ш. Изучение роли молекулярно-биологических маркеров опухоли в выборе метода иммунотерапии в сопроводительном лечении рака яичников и рака шейки матки Евразийский онкологический журнал. 2015. № 2 (5). С. 53-60.

Камышов С.В., Пулатов Д.А., Юлдашева Н.Ш. Изучение роли экстракорпоральной иммунофармакотерапии в снижении токсических эффектов химиолучевой терапии у пациентов с раком шейки матки Евразийский онкологический журнал. 2015. № 4 (7). С. 28-34.

Камышов С.В., Пулатов Д.А., Ахмедов О.М., Саидова К.А., Алиева Д.А., Гильдиева М.С., Нишанов Д.А. Влияние экстракорпоральной иммунофармакотерапии на внутриклеточный метаболизм у пациентов с раком шейки матки Евразийский онкологический журнал. 2018. Т. 6. № 2. С. 551-562.

Камышов С.В. Механизмы иммунных нарушенийу пациентов с раком яичников, получающих химиотерапию, и их динамика на 
фоне иммунотерапии Евразийский онкологический журнал. 2018. Т. 6. № 2. С. 563-576.

Камышов С.В., Юлдашева Н.Ш., Салимова Л.Р. Изучение методов экстракорпоральной иммунофармакотерапии в качестве сопровождения химиотерапии у больных раком яичников Онкология и радиология Казахстана. 2010. № 3-4 (16-17). С. 96.

Юлдашева Н.Ш., Наврузова В.С., Ахмедов О.М., Умарова Н.А., Камышов С.В. Особенности лечебного патоморфоза опухоли при рентгенэндоваскулярной полихимиотерапии в комплексном лечении рака шейки матки Онкология и радиология Казахстана. 2010. № 3-4 (16-17). С. 96-97.

Le Tourneau C, Delord JP, Gonçalves A, et al: Molecularly targeted therapy based on tumour molecular profiling versus conventional therapy for advanced cancer (SHIVA): A multicentre, open-label, proof-of-concept, randomised, controlled phase 2 trial. Lancet Oncol 16:1324-1334, 2015

McNeil C: NCI-MATCH launch highlights new trial design in precision-medicine era. J Natl Cancer Inst 107:djv193, 2015

Sholl LM, Do K, Shivdasani P, et al: Institutional implementation of clinical tumor profiling on an unselected cancer population. JCI Insight 1:e87062, 2016

Zehir A, Benayed R, Shah RH, et al: Mutational landscape of metastatic cancer revealed from prospective clinical sequencing of 10,000 patients. Nat Med 23:703-713, 2017 [Erratum: Nat Med 23:1004, 2017]

Jones S, Anagnostou V, Lytle $\mathrm{K}$, et al: Personalized genomic analyses for cancer mutation discovery and interpretation. Sci Transl Med 7:283ra53, 2015

UDC: 618.11-006
Schrader KA, Cheng DT, Joseph V, et al: Germline variants in targeted tumor sequencing using matched normal DNA. JAMA Oncol 2:104-111, 2016

Mandelker D, Zhang L, Kemel Y, et al: Mutation detection in patients with advanced cancer by universal sequencing of cancer-related genes in tumor and normal DNA vs guideline-based germline testing. JAMA 318:825-835, 2017

Dumbrava EI, Brusco L, Daniels MS, et al: Expanded analysis of secondary germline findings from matched tumor/normal sequencing identifies additional clinically significant mutations. JCO Precis Oncol doi:10.1200/PO.18.00143

Kalia SS, Adelman K, Bale SJ, et al: Recommendations for reporting of secondary findings in clinical exome and genome sequencing, 2016 update (ACMG SF v2.0): A policy statement of the American College of Medical Genetics and Genomics. Genet Med 19:249-255, 2017 [Erratum: Genet Med 19:484, 2017]

Meric-Bernstam F, Brusco L, Daniels M, et al: Incidental germline variants in 1000 advanced cancers on a prospective somatic genomic profiling protocol. Ann Oncol 27:795-800, 2016

National Comprehensive Cancer Network (NCCN): Familial and Genetic High-Risk Assessment: Breast and Ovarian. 2019. Version 3.2019, 112. https://www.

nccn.org/professionals/physician_gls/pdf/genetics_scr eening.pdf

National Comprehensive Cancer Network (NCCN): Familial and Genetic High-Risk Assessment: Colorectal. 2018. Version 1.2018, 97. https://www.nccn.org/ professionals/physician_gls/pdf/genetics_colon.pdf

\title{
REVERSION MUTATIONS IN BRCA1 AND BRCA2 AND RESISTANCE TO PARP INHIBITORS
} AND PLATINUM

DOI: 10.31618/ESU.2413-9335.2019.2.69.483

Islamov Khurshid Djamshidovich

MD, PhD. Head of coloproctology Department of Republican specialized Scientific and Practical Medical Center of Oncology and Radiology of the Ministry of Health of the Republic of Uzbekistan, Tashkent

\begin{abstract}
This article discusses mutations in the BRCA1 and BRCA2 genes and resistance to PARP inhibitors. АННОТАЦИЯ

Key words: PARP inhibitors, BRCA1 and BRCA2 genes, resistance.

Ключевые слова: ингибиторы PARP, гены BRCA1 и BRCA2, резистентность.
\end{abstract} PARP.

В статье рассматриваются мутации в генах BRCA1 AND BRCA2 и резистентность к ингибиторам

Germline pathogenic mutations in BRCA1 and BRCA2 are associated with an increased lifetime risk of breast and ovarian cancers [1]. The tumors that arise in mutation carriers have almost always undergone loss of the wild-type allele, leading to loss of BRCA1/2 function. This, in turn, leads to a profound defect in homology-mediated DNA repair and inappropriate use of error-prone repair pathways, which result in gross genomic instability that contributes to tumorigenesis [2]. This DNA-repair defect in BRCA1/2-mutant cancers renders them exquisitely vulnerable to certain kinds of DNA damage, including those caused by poly (ADP-ribose) polymerase (PARP) inhibitors and certain classic chemotherapy agents, including 